\title{
İnfluenza virüsü (H1N1)'ne sekonder gelişen miyokardit olgusu
}

\author{
A case with myocarditis secondary to Influenza virus (H1N1)
}

\author{
Fesih Aktar $^{1}$, Ali Güneş ${ }^{1}$, Servet Yel ${ }^{1}$, Ercan Çubuk ${ }^{1}$, Fikri Demir ${ }^{2}$, Şeyhmus Mete ${ }^{3}$
}

\section{ÖZET}

Influenza, sağlıklı çocuklarda genellikle kendi kendini sınırlayan, akut ve komplikasyonsuz bir hastalık olsa da nadiren ciddi hastalık tablosu oluşturup ölüme neden olabilir. Enfeksiyonun en sık komplikasyonu pnömoni olup, miyokardit influenza $A$ ve $B$ virüsüne bağlı olarak gelişebilen nadir bir komplikasyondur. 32 aylık erkek hasta ateş, öksürük, kusma, halsizlik, burun akıntısı, sonrasında hızlı gelişen solunum sıkıntısı ve taşikardi şikâyetleri ile kabul edildi. Genel durumu orta, bilinci açık, hepatomegali, taşikardi, dispne, takipne, interkostal-subkostal çekilme ve bilateral ronküs mevcuttu. Kardiak enzim düzeyleri ve diğer laboratuvar parametreler normaldi. Ekokardiyografide miyokardit ve ejeksiyon fraksiyonu $\% 42$ olarak bulundu. Ancak takiplerinin 24-48. saatinde belirgin solunum sıkıntısı gelişen hasta entübe edilip mekanik ventilatöre bağlandı. Hastanın nazofarinks sürüntü kültüründe takiplerinin altıncı gününde H1N1 üredi. Mevcut myokardit tablosunun H1N1 virüsüne bağlı olabileceği düşünülerek Oseltamivir tedavisi başlandı. Tedavinin dördüncü gününde ateşi normale dönen hastanın dokuzuncu gününde kliniğinde dramatik bir iyileşme görüldü. Ekokardiyografi takiplerinde ise ejeksiyon fraksiyonu ve myokardit tablosunda başvuru anına göre belirgin düzelme gözlendi. Gribal enfeksiyon bulgularıyla başvurup solunum sıkıntısı ve taşikardi gelişen hastalarda, alt solunum yolu enfeksiyonu yanında miyokarditin de ayırıcı tanıda düşünülmesi ve erken tanı ve tedavi ile yüz güldürücü sonuçların alınabileceğini hatırlatmak amacıyla sunuldu.

Anahtar kelimeler: Çocuk, H1N1, influenza virüsü, myokardit, oseltamivir

\begin{abstract}
Although influenza is an acute and uncomplicated disease, that limits itself in the healthy children, it may lead to death by rarely forming the sickness. The most common complication of influenza is pneumonia and it is a rare complication which is developed together with myocarditis by influenza A and B viruses. A 32 months-old male patient was admitted for rapidly developed respiratory distress and tachycardia after fever, cough, vomiting, malaise and runny nose. His general status was medium, he had conscious and had hepatomegaly, tachycardia, dyspnea, tachypnea, intercostal-subcostal retractions and bilateral rhonchus. Cardiac enzyme levels and other laboratory parameters were found normal. Myocarditis and ejection fraction was determined as $42 \%$ in echocardiography. However, hospitalization hours between 24 and 48 , the patient, whose significant respiratory compromise developed, was intubated and fastened to a mechanical ventilator. $H 1 N 1$ is produce in nasopharyngeal swab culture at the sixth day of follow-up. Because we think H1N1 virus was responsible from current myocarditis, oseltamivir treatment was initiated. In the fourth day of the treatment the patient's fever returned to normal, in the ninth day a dramatic recovery was observed. In tracking echocardiography, a significant improvement was observed in the ejection fraction and myocarditis picture compared with admission time. This case was presented in order to remind that in a patients, who present with influenza findings but have respiratory distress and tachycardia in addition to lower respiratory tract infection, myocarditis should also be considered in the differential diagnosis and to remind that promising results could be obtained with the early diagnosis and treatment.
\end{abstract}

Key words: Child, H1N1, influenza virus, myocarditis, oseltamivir

${ }^{I}$ Dicle Üniversitesi Tıp Fakültesi Çocuk Să̆lı̆̆ ve Hastalıkları AD, Diyarbakır, Türkiye

${ }^{2}$ Dicle Üniversitesi Tıp Fakültesi Çocuk Sağlığı ve Hastalıkları, Çocuk Kardiyoloji BD, Diyarbakır, Türkiye

${ }^{3}$ Diyarbakır Kadın Doğum ve Çocuk Hastalıkları Hastanesi, Çocuk Sağlı̆̆ı ve Hastalıkları Bölümü, Diyarbakır, Türkiye

Yazışma Adresi /Correspondence: Fesih Aktar,

Dicle Üniversitesi Tıp Fakültesi Çocuk Sağlığı ve Hastalıkları AD, Diyarbakır, Türkiye Email: fesihaktar@yahoo.com

Geliş Tarihi / Received: 06.08.2015, Kabul Tarihi / Accepted: 07.09.2015

Copyright (C) Dicle Tıp Dergisi 2015, Her hakkı saklıdır / All rights reserved 


\section{GíRiş}

İnfluenza virüsü (H1N1), sağl1klı çocuklarda genellikle kendi kendini sınırlayan, akut ve komplikasyonsuz bir hastalık olsa da nadiren ciddi hastalık tablosu oluşturup ölüme neden olabilir. Hastalar sıklıkla boğaz ağrısı, öksürük, ateş, halsizlik, baş ağrısı, miyalji ve artralji şikâyetleri ile başvurmaktadırlar. Enfeksiyonun en s1k komplikasyonu pnömoni olup, miyokardit influenza A ve B virüsüne bağlı olarak gelişebilen nadir bir komplikasyondur [1].

$\mathrm{Bu}$ olgu, gribal enfeksiyon bulgularıyla başvurup solunum sıkıntısı ve taşikardi gelişen hastalarda, alt solunum yolu enfeksiyonu yanında miyokarditin de ayırıcı tanıda düşünülmesi ve erken tanı ve tedavi ile yüz güldürücü sonuçların alınabileceğini hatırlatma amaciyla sunuldu.

\section{OLGU}

Otuz iki aylık erkek hasta son beş gündür ateş, öksürük, kusma, halsizlik, burun akıntısı, sonrasında hızlı gelişen solunum sıkıntısı ve taşikardi şikâyetleri ile diş merkezden çocuk yoğun bakım ünitemize pnömoni ve kalp yetmezliği ön tanılarıyla kabul edildi. Öyküsünde kronik bir hastalığ 1 ve çevresinde benzer şikâyetleri olan yoktu. Fizik muayenesinde; genel durumu orta, bilinci açık, vücut sıcaklığı: $38,3^{\circ} \mathrm{C}$, solunum say1s1: $46 / \mathrm{dk}$, kalp tepe atımı: 160 /dk, kan basınc1: 87/55 mmHg, oksijenli satürasyonu: \%85-90 idi. Hastanın dispne, takipne, interkostal ve subkostal çekilmeleri ve akciğerlerinde bilateral ronküsleri mevcuttu. Hepatomegalisi de olan hastada, kalp sesleri normaldi.

Laboratuvar incelemesinde; tam kan sayım1, biyokimyasal parametreler, sedimantasyon hiz1, C-reaktif protein ve kardiak enzim düzeyleri normal bulundu. Kan gazında hafif bir respiratuvar asidoz dışında anormallik yoktu. Çekilen posteroanterior akciğer grafisinde yamalı infiltrasyonlar ve konsolide alanlar mevcuttu.

Elektrokardiyografik incelemesi normaldi. Ekokardiyografide (EKO) miyokardit ve ejeksiyon fraksiyonu $\% 42$ tespit edilen hastaya inotrop desteği başlandi (Resim 1).

Ancak takiplerinin 24-48. saatinde belirgin solunum sıkıntısı gelişen, oksijen satürasyonu düşen ve parsiyel karbondioksit basıncı yükselen hasta entübe edilip mekanik ventilatöre bağlandı. Hastaya profilaktik antibiyotik başland.

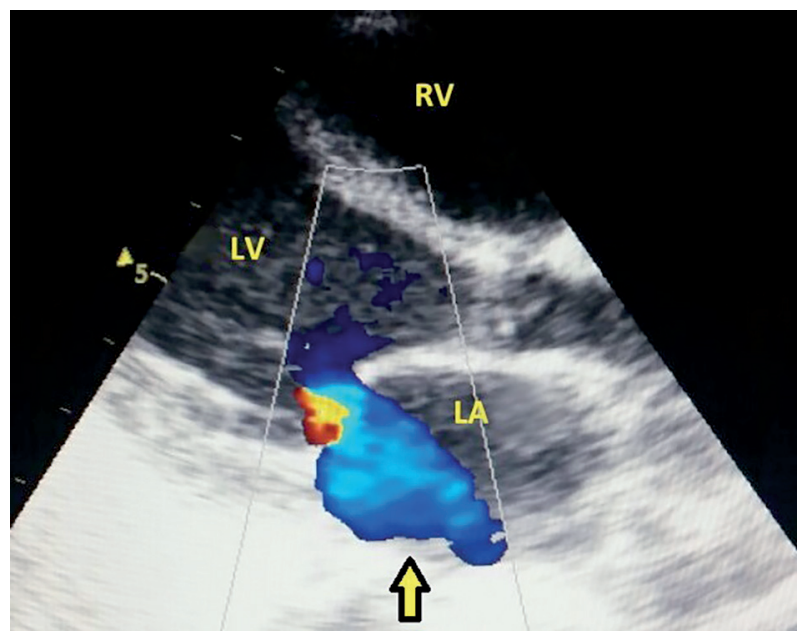

Resim 1. Sol ventrikül sistolik disfonksiyonu ve mitral yetersizliğini (ok ile gösterilmiş) gösteren ekokardiyografik parasternal uzun eksen görüntüsü. LA: sol atrium, LV: sol ventrikül, RV: sağ ventrikül

Hastanın başvuru anında nazofaringeal sürüntüden alınan viral serolojide takiplerinin altıncı gününde $H 1 N 1$ üredi. Diğer kültür sonuçları normaldi. Olgumuz mevcut solunum sıkıntısı, ateşle uyumsuz taşikardi ve ekokardiyografi bulguları ile birlikte myokardit tanıs1 ald1. Myokardit tablosunun da H1N1 virüsüne bağlı olabileceği düşünüldü. Hastaya Oseltamivir tedavisi başlandı. Tedavinin dördüncü gününde hastanın ateşi normale döndü. Tedavinin dokuzuncu gününde kliniğinde dramatik bir iyileşme görüldü. Oseltamivir tedavisi üç haftaya tamamland1. Ekokardiyografi takiplerinde ise ejeksiyon fraksiyonu ve myokardit tablosunda başvuru anına göre belirgin düzelme gözlenen hasta şifa ile taburcu edildi.

\section{TARTIŞMA}

İnfluenza, akut bir solunum yolu enfeksiyonu olup alt veya üst solunum sistemini etkileyebilen, kişiden kişiye damlacık yoluyla bulaşan ve kuluçka süresi 1-4 gün olup; nadiren yedi güne kadar da uzayabilen bir patojen olduğu bildirilmiştir [1]. Olgumuzun şikayetleri 5 gün önce non-spesifik semptomlarla başlamıştı ve çevresinde benzer şikayeti olan yoktu. 
İnfluenzanın klinik tablosu hafif bir üst solunum yolu infeksiyonundan yaşamı tehdit eden ağır bir hastalığa kadar değişebilir [2]. Hafif ve komplikasyonsuz influenzada klasik influenza semptomlar1 görülürken, ağır veya komplikasyonlu influenzada pnömoni, santral sinir sistemi bulguları, ağır dehidratasyon, böbrek yetmezliği, multiorgan yetmezliği, miyokardit, rabdomiyolizis, invaziv sekonder bakteriyel infeksiyon veya septik şok görülebilir $[1,3,4]$. Myokardit tablosu ise viral, bakteriyel, riketsiyal, mikotik ve parazitik enfeksiyonlara bağ11 olarak gelişebilir. Bu tabloda, özellikle Koksaki virüs, Adenovirüs ve Ekovirüs olguların büyük bir kısmından sorumludur. Bunun dışında Ebstein Barr virüs, Sitomegalovirüs, HIV, klzamık, kabakulak, klzamıkçık ve nadiren de Ínfluenza tip $A$ ve $B$ de miyokardit tablosuna yol açabilir [2]. Miyokardit olgularında yaşlara göre klinik bulgu oluşurken takipne, ateşle uyumsuz taşikardi, kalp seslerinin derinden gelmesi ve kalp yetersizliği ortak bulgulardandır. Tanıda klinik bulguların yanında telekardiyogramda kardiyomegali; EKG değişiklikleri; kardiak enzim yüksekliği ve EKO'da sol ventrikül işlevlerinin bozuk olması da önemlidir [2]. İnfluenzaya tanı koyma sürecinde en önemli nokta ise hastanın influenza olabileceği şüphesini akla getirmektir [5]. Tanı nazofarengeal sürüntü veya nazal salgıdan alınan örnekte virüsün PCR (polimeraz zincir reaksiyonu) ile gösterilmesi yoluyla konulabilmektedir $[1,4,5]$. Bizim olgumuz takipne, dispne, interkostal-subkostal çekilme, ani gelişen ateşle uyumsuz taşikardi ve EKO bulguları ile myokardit tanıs1 ald1. Elektrokardiyografi ve kardiak enzim düzeyleri normaldi. Başvuru esnasında üst solunum yolu enfeksiyonu bulgular1 olan hastamızdan bakılan nazofarengeal sürüntü kültüründe H1N1 üredi. Diğer kültür sonuçları normal olan olgumuzda myokarditin olas1 nedeninin $H 1 N 1$ olabileceği düşünüldü.

Hafif ve kendiliğinden düzelen H1N1 influenzalı çocukların ilk akciğer grafilerinin sıklıkla normal olduğu, nadiren anormal radyolojik bulguların saptandığ 1 ve bunlar arasında en sik görülenlerin belirgin peribronşiyal kalınlaşmalar ile birlikte akciğerlerde havalanma fazlalığ 1 olduğu rapor edilmiştir $[1,4]$. Hastaneye yatırılan çocuklarda pnömoni dişında komplikasyonlara yol açabilen bakteriyel koinfeksiyonlar da bildirilmiştir [6]. Olgumuzun başvuruda çekilen akciğer grafisinde yamalı in- filtrasyonlar ve konsolide alanlar dışında patolojik bulgu saptanmadı. Hastamızın başvuru anında ve takiplerinde alınan kan ve nazofarengeal aspirat kültürlerinde patojen bir etken saptanmazken sadece başvuru anında alınan nazofarengeal sürüntü kültüründe $H 1 N 1$ tespit edildi.

ABD, Arjantin ve Kanada'dan yapılan yayınlarda H1N1 influenza nedeniyle hastaneye yatırılan çocukların \%19-21'inin yoğun bakım gereksinimi gösterdiği, \%10-17'sinin ise mekanik ventilasyon gerektirdiği rapor edilmiştir [6,7]. Hastaneye yatırılan çocuklarda mortalite oranları $\% 5$ olarak belirtilmektedir [6]. Hastamızın başvuru anında ileri solunum desteğine ihtiyac1 yoktu. Olgumuzda ortaya çıkan ve hızlı gelişen ateşle uyumsuz taşikardi ve kalp yetmezliği bulguları ile myokardit tanısı konulup inotrop tedavi başlanması ve profilaktik antibiyotik tedavilerine devam edilmesine rağmen takiplerinin 2. gününde belirgin bir klinik bozulma gözlenen hastamızın mekanik ventilasyon ihtiyacı gelişti.

Olası veya kanıtlanmış influenza A virüsü infeksiyonu olan kişilerden yalnızca hastalığın komplikasyon ve mortalite riski yüksek olanlara antiviral tedavi önerilmektedir $[1,3,4]$. Oseltamivir ve zanamivir ile önerilen tedavi süresi beş gündür $[3,4]$. Hastanede yatan ağır influenza hastalığı olan kişilerde daha uzun süreyle antiviral tedavi gerekebileceği bildirilmiştir [3]. Literatürlerde her ne kadar oseltamivir tedavisinin hastalığın erken dönemlerinde uygulanmasının olumlu sonuçlara yol açabileceği bildirilse de olgumuzda başvuru anında myokardit tanıs1 konmasına rağmen ancak takiplerinin 6 . gününde sürüntü kültür pozitifliği saptanması üzerine hastamıza oseltamivir tedavisi uygulayabildik. Tedavinin 9. gününde ise hastamızın kliniğinde dramatik bir iyileşme görüldü. Ancak takip süresince solunum komplikasyonlarının ağırlaşması nedeniyle maalesef olgumuzda birkaç kez solunum arresti meydana geldi. Bu nedenle olgumuzu ağır influenza tablosu olarak değerlendirip oseltamivir tedavisini de 3 haftaya tamamlayıp sonraki dönemlerde ek bir komplikasyon gelişmeden hastamız taburcu edilmiştir.

Sonuç olarak, H1N1 enfeksiyonunun en s1k komplikasyonu pnömoni olsa da, gribal enfeksiyon bulgularını izleyerek gelişen akut solunum sıkıntısı ve ateşle uyumsuz taşikardi geliştiğinde H1N1'in 
nadir bir komplikasyonu olan myokarditin de ay1rıc1 tanıda düşünülmesi, erken dönemde viral enfeksiyonlara yönelik kültürlerin alınması önemlidir. Ayrıca virüs ile ilişkili myokardit tablosunun ciddi hastalık bulgusu olduğu, hastalara destek tedavileri yanında geç dönemde de olsa oseltamivir tedavisinin uzun süre kullanılmasının mortaliteyi önleyebileceğini vurgulamak istiyoruz.

\section{KAYNAKLAR}

1. Jain R, Goldman RD. Novel influenza A (H1N1): clinical presentation, diagnosis, and management. Pediatr Emerg Care 2009;25:791-796.

2. Park MK. Pediatric cardiology for practitioners. $5^{\text {th }}$ ed. Philadelphia: Mosby Elsevier, 2008: 360-367.

3. Centers for Disease Control and Prevention (CDC). H1N1 flu. Updated interim recommendations for the use of antivi- ral medications in the treatment and prevention of influenza for the 2009-2010 season. Atlanta, GA: Centers for Disease Control and Prevention; 2009. Accessed date: 26.04.2015. Available from: http:/www.cdc.gov/H1Nlflu/recommendations.htm

4. Sullivan SJ, Jacobson RM, Dowdle WR, Poland GA. 2009 H1N1 influenza. Mayo Clin Proc 2010;85:64-76.

5. Harper SA, Bradley JS, Englund JA, et al. Seasonal influenza in adults and children--diagnosis, treatment, chemoprophylaxis, and institutional outbreak management: clinical practice guidelines of the Infectious Diseases Society of America. Clin Infect Dis 2009;48:1003-1032.

6. Libster R, Bugna J, Coviello S, et al. Pediatric hospitalizations associated with 2009 pandemic influenza A (H1N1) in Argentina. N Engl J Med 2010;362:45-55.

7. Jain S, Kamimoto L, Bramley AM, et al. Hospitalized patients with 2009 H1N1 influenza in the United States, AprilJune 2009. N Engl J Med 2009;361:1935-1944. 